\title{
Where Does CSR Come from and Where Does It Go? A Review of the State of the Art
}

\author{
Sara Rodriguez-Gomez * ${ }^{\mathbb{D}}$, Maria Lourdes Arco-Castro $\mathbb{D}^{\text {, }}$, Maria Victoria Lopez-Perez $\mathbb{D}$ and \\ Lazaro Rodríguez-Ariza
}

Department of Finance and Accounting, University of Granada, 18072 Granada, Spain; mlarco@ugr.es (M.L.A.-C.); mvlopez@ugr.es (M.V.L.-P.); lazaro@ugr.es (L.R.-A.)

* Correspondence: sara@ugr.es

Received: 3 August 2020; Accepted: 17 August 2020; Published: 20 August 2020

\begin{abstract}
It can be said that business ethics are integrated into companies through Corporate Social Responsibility (CSR), which cannot be defined in a single way, nor has its concept remained unchanged since its appearance in the business world. The contributions made in the field of research have been evolving towards models and theories that are more in line with principles that consider a plurality of stakeholders, from utilitarian or shareholder-centered approaches to others that are more integrative; the consideration of the demands and requirements of stakeholders, and the institutional drive through the establishment of regulatory frameworks aimed at providing conceptual frameworks of reference and indicators that make it possible to manage and make decisions taking into account the ethical dimension of problems or conflicts, are decisive. In this area, the objectives of sustainable development as part of Agenda 2030 are particularly relevant and are providing a boost to innovations aimed at improving the environment and the rational use of resources. This paper attempts to gather the main conceptual contributions on the situation and evolution of CSR, providing insights regarding future CSR studies, its objectives, and goals which, together with the interests and positions of the stakeholders from different perspectives, raises the possibility of analyzing CSR from different points of view, giving rise to different theories that try to serve as a framework for the study of CSR.
\end{abstract}

Keywords: corporate social responsibility; stakeholders; sustainability; innovation

\section{The Evolution and Concept of Corporate Social Responsibility}

\subsection{The Context in Which CSR Takes Place and Its Evolution}

The labor conflicts that developed at the end of the 19th century as a result of the industrial revolution, when the model of artisan work was changed to one of mass production, revealed a series of social problems that forced companies to take measures that could be considered as the origin of CSR (Jenkins 2009).

During the 1950s and 1960s, the capitalist model, which advocated profit maximization and self-regulation of markets, revealed negligent actions that led to the violation of human and labor rights by companies. Faced with this reality, voices emerged in society demanding more responsible action by companies in relation to social aspects (Gomez-Carrasco et al. 2016) and far-reaching institutional initiatives such as the Universal Declaration of Human Rights, which took place in 1948.

The 1970s were influenced by a severe economic crisis, which led to the emergence of a number of social movements that played a key role in introducing environmental, civil rights, and women's rights issues into companies, among others (Carroll and Shabana 2010).

Throughout the 1980s and 1990s, concern began to be expressed about the impact that human actions, including those developed by companies, was having on the environment, and numerous 
summits of international bodies were held in relation to both this issue and the concerns already expressed about human and labor rights (Salvioli 2000). In these first moments, the objective of the CSR policies is directed to improve the image and reputation of the companies, looking to obtain the social legitimization to be able to act (Carroll 2008).

In the 2000s, the globalization of markets and with it, the freedom to operate on the part of companies, as well as the greater complexity of the relations of companies with the various social groups or interest groups, caused a further step towards the change of company model (Cornelius et al. 2007; Shnayder et al. 2016). CSR became a fundamental element in companies' responses to various social requirements (Jamali 2008), understood as the way in which companies assumed social commitments and responsibilities, taking into account the impact of their operations on stakeholders, thus, generating the trust that allowed them to operate in different markets (Jamali 2008; Panait et al. 2014; Tello and Rodríguez 2014). At first, these were voluntary requirements, but they were widely accepted by the companies. In addition, at the institutional level, the proposal of codes of good practice for corporate governance in the various countries was encouraged.

This process can be said to have culminated in the 2000s in a change in CSR towards integration in business strategies (Arco-Castro et al. 2020). CSR becomes part of the core business and begins to be studied in relation not only to obtaining competitive advantages or efficiency in the use of resources, but also becomes the reference point for promoting policies in the company, with innovation being a central aspect in all areas, but mainly in the environmental field (García-Sánchez and Araújo-Bernardo 2020).

\subsection{The Development of CSR in the Business World}

Although CSR has become a topic of study of increasing interest in recent decades (Carroll and Shabana 2010; Park et al. 2014; O'Riordan and Fairbrass 2014), the concept first appeared in the late 1930s, although not explicitly, as it was considered that, in the decision-making process, economic, legal, moral, social, and physical elements should be combined (Barnard 1938). On the same line, it was demanded that managers respect the values of society, going beyond the legal requirements (Simon 1945).

Nevertheless, despite these early contributions to the literature on CSR, it could be considered that today's CSR has its origins in the mid-1950s (Carroll 1999), when it began to be argued that companies should make commitments beyond obtaining profits and that they should take into account their employees, customers, and the general public (Abrams 1951). It can be said that CSR as a subject of study began at least seven decades ago, when in a publication in Fortune magazine (1946), the editors suggested that CSR implied that businessmen were responsible for the consequences of their decisions and actions beyond the scope of their profit and loss account (Kolodinsky et al. 2010).

In the book "Social Responsibilities of the Businessman", Bowen (1953), considered the father of the idea of CSR, defined it as the group of obligations of employers related to the adoption of policies and the development of lines of action that respond to the values and desires of society (Carroll 1999). Although the word obligation was used, it should be understood only in a moral sense, since during this period, companies that adopted this social approach did so voluntarily (Bhaduri and Selarka 2016; Frederick 2016).

Advancing in the next decade, we continue to find authors who defend that CSR is linked to the responsibilities of companies with respect to shareholders, the greatest exponent of which is Friedman, who argued that corporate social responsibility consisted of using resources to carry out activities designed to obtain long-term benefit, as long as they were carried out within free competition without deceit or fraud (Friedman 1962). Only a few years later, the concept of CSR began to expand, linking it to compliance with laws in response to social demands (Frederick 2016). Companies have a power that needs to be controlled, with the law being the control mechanism that makes companies responsible, protecting the welfare of society in general (Hetherington 1969).

In the late 1960s, the term stakeholders appeared to refer to those who had a legitimate interest in the entity. This term reveals an intimate relationship between companies, society, and all those social groups 
that could be affected by the actions of these companies (McGuire 1963; Walton 1967). The introduction of this concept entails the inclusion in the business environment of ethical aspects, along with other moral and philosophical aspects (Banks 1975; Epstein 1976). This vision still coexists with that of other authors who continue defending Friedman's position, that is, the maximization of results, and a unique responsibility towards the shareholders (Friedman 1970). At this stage, the consideration of the owner or responsible individual began to open to the concept of corporate responsibility, already considering companies as responsible entities and capable of acquiring commitments as "good corporate citizens" (Davis 1973).

During the 1980s, another significant change was introduced in the consideration of CSR, as it was understood as an area that needed to be managed, like other aspects of the company, and that formed part of the daily activities of organizations. Companies analyze the social consequences of their decisions (Epstein 1987; Jones 1980; Epstein 1987). In this period, CSR is more linked to actions taken to counteract negligent actions than to proactive ones. Freeman (1984) establishes, as a theoretical framework for analyzing corporate CSR, the theory of stakeholders, understanding that entities must manage the demands of stakeholders, which would be those interest groups that are affected by the actions of the company or could affect its operations. Even so, a significant number of studies in these years analyze the effects that the various CSR policies have on financial performance indicators, in an attempt to justify their impact on obtaining profits, albeit with disparate results (Aupperle et al. 1985; Cochran and Wood 1984). Although in the first place, it was a question of responding to shareholders and how they were affected financially, the search for indicators that made it possible to determine the factors affected CSR in companies, and which caused variations in the financial performance indicators, was beginning (del Mar Miras-Rodríguez et al. 2013).

In the 1990s, business schools introduced ethical education into their training for entrepreneurs. Thus, business ethics became a subject of research at this time (Donaldson and Dunfee 1994; Robertson 1993). Authors began to ask what could be the different factors that influence the ethical conduct in a company, distinguishing those that affect the decision makers. In this sense, they point out as fundamental factors personal characteristics such as age (Arlow 1991), gender, ethnicity (Ford and Richardson 1994), education (Kennedy and Lawton 1998), religion (Quinn 1997) or personality (Trevino 1992); and others that we can call situational factors such as the environment, the sector, the competitiveness of the industry, the establishment of a system of sanctions and/or awards, the existence of codes of conduct, or the size of the organization or the country factor, among others (Ford and Richardson 1994).

The 21st century is characterized by the globalization of commercial and financial relations that implies constant changes in the economic environment and in economic and social progress (McGuire et al. 1988), so CSR becomes an important corporate decision that affects both sustainability and stakeholders (Dahlsrud 2008). We find studies that continue to maintain that the motivation of companies to be more socially responsible is to obtain greater profitability compared to their less socially committed competitors (Orlitzky et al. 2003; Vogel 2005). At this stage, studies already appear in which innovation is related to CSR, although without going into detail (McWilliams et al. 2006).

In recent years, the relevance of CSR in companies has increased exponentially, representing not only a business opportunity, but also a reflection on the expectations of stakeholders to be considered, thus, demonstrating a strong connection between business success, competitiveness, and sustainability (Closon et al. 2015). CSR has gone from being an isolated and specific idea to a widely recognized and demanded business practice (Lee 2008), which must be integrated into the core of the business and the business strategy (Kim et al. 2018), becoming a fundamental element in strategic business management, together with other areas of the company (Hsieh et al. 2008). In this context, CSR represents the way in which companies contribute to meeting the demands and requirements of stakeholders and especially, the role they play in ensuring long-term sustainability (Fernández-Guadaño and Sarria-Pedroza 2018; Vázquez et al. 2013). The evolution of the concept of CSR is shown in Figure 1. 
Although CSR is a recurring theme in both economic and academic contexts, there is no agreement on how it should be defined, measured, and the hierarchy of aspects that make it up. This situation may be due to the lack of consensus on the aspects that are an inalienable part of corporate social responsibility, or to the fact that its concept has been changing over the years. Although they have points in common (Dahlsrud 2008), it is necessary to establish differences between the different conceptualizations, which will help in understanding the evolution that has taken place and situating us where we are at the current time.

Three areas of CSR recurring in most definitions are economic, social, and environmental (Chowdhury et al. 2019; Marí-Farinós 2017; Uribe-Macías et al. 2018). The economic area of CSR has evolved from the sole obligation of accountability to shareholders (Carroll 1991; Friedman 1962; Friedman 1970) and analyzing the impact of actions on financial performance, to broadening its scope in the sense of considering other aspects, such as the capacity to create jobs, research leading to the discovery of new resources or new applications for them, as well as innovation and the promotion of technological progress (Jamali 2008).

The social area is intimately related to human resources (Lu et al. 2019), both those who are part of the company and those who are in its environment (Marí-Farinós 2017). The company's responsibility towards employees and society in general is contemplated in the social dimension of CSR (Jamali 2008; Shnayder and Van Rijnsoever 2018). CSR is considered from this area as a business practice aimed at satisfying and balancing the interests of these stakeholders (Maclagan 2008), so the company must know and take into account the specific characteristics and requirements of these stakeholders (Turner et al. 2019).

The environmental area refers to the obligation of companies to take care of the environment, understanding the fundamental role it plays in obtaining sustainable development and taking into account the effects that it may have on climate change ( $\mathrm{Lu}$ et al. 2019; Marí-Farinós 2017; Taliento et al. 2019).

Many of the research studies carried out on CSR have found relationships between the company's social, environmental, and financial and economic performance (Brogi and Lagasio 2019; Chowdhury et al. 2019; Taliento et al. 2019), concluding that the three dimensions are interconnected, and joint action ensures long-term sustainability. Likewise, all of them have a bearing on the generation of value for stakeholders in the long term, on the improvement of the relationship between stakeholders and the company, and on management's control and planning mechanisms that protect stakeholders' interests and expectations (Cupertino et al. 2019; Jamali 2008; Pirnea et al. 2011). Through the development of CSR practices, the reconciliation of social and economic objectives and the reconciliation of the interests of the company and society are achieved (Bagire et al. 2011; Degie and Kebede 2019; Park et al. 2014; Saiia et al. 2003).

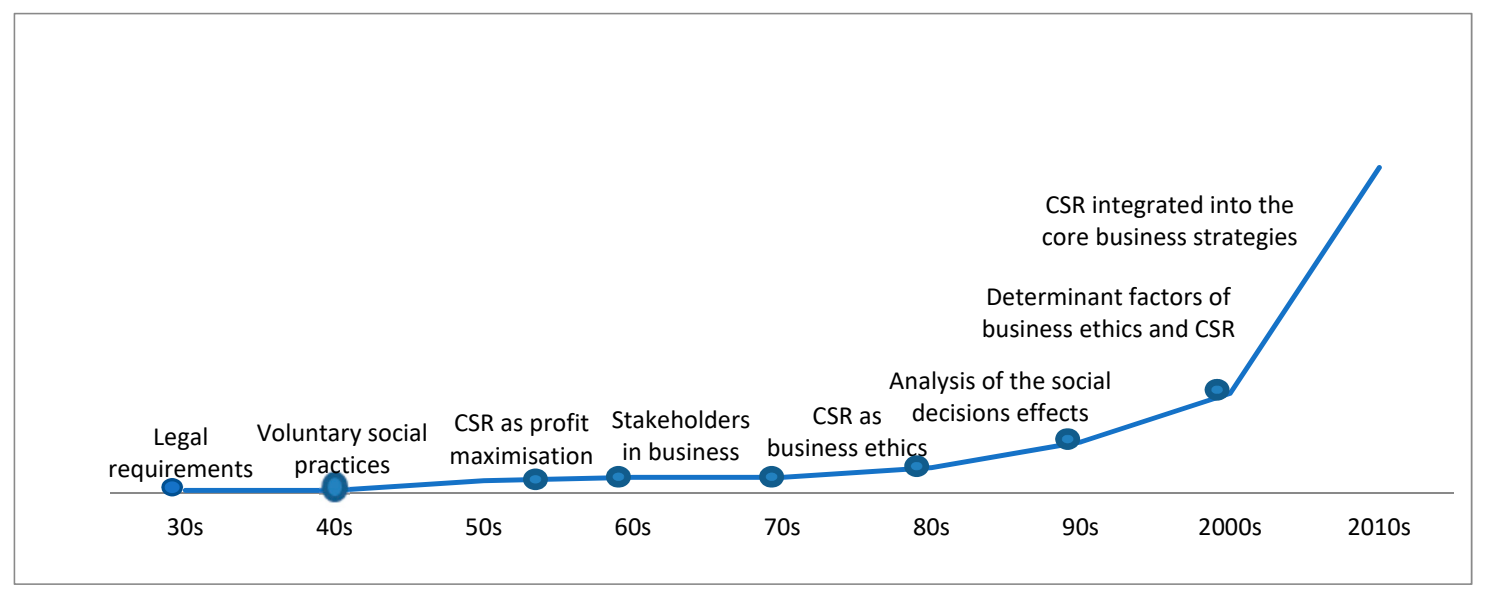

Figure 1. Evolution of CSR concept. 


\section{The Objectives and Purposes of Corporate Social Responsibility}

In the business world, the objectives and purposes of CSR have evolved over time. In the early days of CSR, it was considered exclusively as a marketing tool aimed at achieving legitimacy or improving image. Today, however, it is considered a fundamental strategic element in organizations, essential for the long-term sustainability of companies (Dey et al. 2018). If we analyze the research carried out since the appearance of CSR, we can distinguish five objectives that have been developed over time. These objectives should not be considered to have been surpassed, but rather they coexist, sometimes within the company itself, which adds a certain amount of complexity to the analysis of CSR (Carroll and Shabana 2010).

Some of the research works carried out argue that CSR is a marketing tool that improves image, creates a good corporate reputation, and legitimizes the company's performance (Carroll and Shabana 2010; Wang and Gao 2016; Wójcik 2018). From this perspective, businesses would seek community acceptance for their operations (Wójcik 2018). This objective is framed in the so-called license to operate, which would be "social license", without which a company would have to face problems not directly related to the management of its daily activities, such as conflicts with the community (Syn 2014; Wilson 2016). The concept of reputation has expanded to include the set of beliefs and perceptions of different individuals and groups about the actions of a particular company (Rothenhoefer 2019). From this perspective, the company is considered to carry out CSR actions as a means of achieving or improving corporate reputation (Wang and Gao 2016). Most of these studies on reputation have, in turn, been related to financial performance indicators, although there are also those that analyze the effect on stakeholder relations (Verčič and Ćorić 2018). Depending on the stakeholder or interest group to which the action is directed, we can speak of economic legitimation, if it is a question of justifying the actions with regard to the shareholders; legal legitimation, if it is a question of demonstrating compliance with the regulatory frameworks established by authorized standardization bodies; political legitimization, more typical of communist countries, which usually require certain philanthropic practices that must be justified to the competent institutions; and, finally, social legitimacy (Lock and Schulz-Knappe 2019), this being understood as the consideration, by the community, that the various operations that the company carries out are adequate, appropriate, and necessary in accordance with a social system made up of norms, beliefs, values, and principles (Suchman 1995).

Secondly, CSR could aim to achieve a competitive advantage through the reduction of business risk and associated costs. Some studies conclude that a company's environmental performance improves efficiency through reduced energy and resource costs, costs associated with compliance with environmental legislation, and other costs associated with business operations (Lister 2018). Finally, CSR could avoid the negative effects on profitability of internal and external factors, such as fluctuations in demand due to consumer boycotts, poor employee commitment, product quality problems, supplier-related scandals, etc. (Bouslah et al. 2018; Kim et al. 2019).

The third objective of CSR is to improve relations with stakeholders (Pirnea et al. 2011). This analyzes how CSR increases trust in the relations between a company and its stakeholders (Brower et al. 2017; Flammer 2018; Thorne et al. 2017). As a consequence of this objective, the importance of disseminating information on CSR is highlighted, as it allows communication with different stakeholders, sending different signals to the market and receiving responses from it (Bae et al. 2018). Business reports usually reflect information of a social and environmental nature (Havlová 2015).

Fourthly, another objective of CSR is to create win-win scenarios. This objective is based on the idea that meeting the demands of stakeholders simultaneously involves not only the benefit of stakeholders and society in general, but also the achievement of business objectives of financial performance (del Mar Miras-Rodríguez et al. 2014), with the understanding that economic and financial interests depend on the social and environmental performance of the company (Godfrey et al. 2009; Luo and Bhattacharya 2009). CSR activities will have a positive impact on financial performance (Margolis and Walsh 2003; Orlitzky 2011; Rost and Ehrmann 2017), while 
it could also be a tool for building trust, also called social capital, because it facilitates cooperation in the search for mutual achievements between institutions and different stakeholders (Fisher et al. 2009; Lins et al. 2017; Spence et al. 2003). Some studies bring together the two previous positions and state that CSR practices are vital for building positive relationships with company stakeholders and generating assets such as social capital or trust (Cantrell et al. 2015; Hameed et al. 2016; Lins et al. 2017), which ensures that financial performance is maintained, even in adverse situations (Amin-Chaudhry 2016; Bouslah et al. 2018; Lins et al. 2017). This objective considers the concept of Creating Shared Value (CVC) defined as "operational policies and practices that improve a company's competitiveness while promoting economic and social conditions in the communities in which it operates" (Porter and Kramer 2006), which would be enhanced through the CSR (Nazzaro et al. 2020).

Fifth, and as a result of the increasing awareness of the strong social and environmental impact of companies, CSR would aim at long-term sustainability (Brønn and Vidaver-Cohen 2009; Marí-Farinós 2017; Schönherr et al. 2017). To this end, CSR must be integrated into the strategy and the various business actions, allowing the management of the three areas included in the triple bottom line-the economic, the social, and the environmental (Schönherr et al. 2017). This ensures that actions go beyond the short term or cover immediate objectives (Ashrafi et al. 2018). In relation to this point, we will refer more specifically to one of the actions-innovation strategy and its relationship with CSR-due to its relevance in recent years.

The relationship between CSR and innovation has been the subject of analysis in the literature in recent years (Martínez-Conesa et al. 2017). Studies can be divided into two large groups depending on the unilateral or bidirectional nature of the relationship between CSR and innovation. The first group includes those studies that maintain that CSR policies influence innovation (Halkos and Skouloudis 2018) or that the company's capacity for innovation is a necessary organizational factor for the implementation of CSR (Kalkanci et al. 2019; Zeimers et al. 2019). The second group considers the existence of a bilateral relationship between both variables, i.e., innovation and CSR would influence each other (Gallego-Álvarez et al. 2011; González-Ramos et al. 2014; Rexhepi et al. 2013). According to the latter group, innovation and CSR are two practices that should be complementary for the generation of value in the company (Rexhepi et al. 2013). This is particularly relevant in the environmental area.

In the analysis of the relationship, it is generally approached from an ethical perspective (Chang 2011) and more recently, from a strategic perspective (Martínez-Conesa et al. 2017; Zhou et al. 2020). From the ethical perspective, some studies maintain that innovation in itself can generate social benefits such as the generation of cheaper products, which improve purchasing power, or the generation of new jobs (Kalkanci et al. 2019). The adoption of this innovation would entail R\&D expenses in the company that might not have an impact on the improvement of business performance (Martínez-Conesa et al. 2017).

At the same time, the strategic perspective, which is in the majority today, postulates that innovation is the result of integrating CSR into business strategy. From this approach, CSR would be oriented towards the search for value creation in terms of innovation (Martínez-Conesa et al. 2017; Zhou et al. 2020). In this case, innovation on CSR not only implies expenditure on R\&D but could also achieve better organizational performance. Innovation would increase operational efficiency with the use of cleaner technologies and increase the capacity to generate value derived from the efficient planning of factory operations (Geissdoerfer et al. 2016). CSR would also improve the financial performance of the entity through the development of innovative practices, processes, and products that enhance the company's competitive advantage through differentiation and cost-saving strategies (Luo and Du 2015; Rexhepi et al. 2013). Finally, other studies consider that CSR linked to stakeholder management drives innovation in response to stakeholder demands by improving the social performance of the company (Li 2020; Weng et al. 2015). Thus, through innovation in ecological products, the needs of a consumer who is increasingly committed to environmental issues are met (Waheed et al. 2020).

These CSR-related innovation processes have traditionally focused on ecological innovation or eco-innovation (Baumann et al. 2002; Bocken et al. 2011; Waheed et al. 2020), which has its origin in the goal of achieving sustainable development, i.e., the search for a business model that meets 
current needs without compromising the needs of future generations (WCED 1987), and which is gaining strength today, due to the fact that environmental problems are becoming increasingly worrying (Shahzad et al. 2020). Thus, recent studies focus on the development of concepts such as sustainability-oriented innovation or green innovation (Adams et al. 2016; Shahzad et al. 2020), which would include the means by which an organization can reduce the adverse effects of its operations on the natural environment (Shahzad et al. 2020) and also the pursuit of "sustainable business models" (Geissdoerfer et al. 2016; Hu et al. 2020), i.e., the development of an environmentally responsible corporate posture that involves a change in values and philosophy, practices, and processes in order to create social, environmental, and economic value (Adams et al. 2016; Geissdoerfer et al. 2016).

These objectives, which we have been identifying separately, cannot be considered exclusive, insofar as they are interrelated. Some studies indicate that, in order to achieve the long-term sustainability objective, other objectives such as value creation (Ashrafi et al. 2018; Dyllick and Muff 2016), competitive advantage (Santos et al. 2009), the legitimization of the actions, the stakeholders' perception of the entity (Harjoto and Salas 2017; Tollin and Christensen 2019), and the credibility and reliability of the actions as a signal to the stakeholders ensure that the various agents involved see their demands and interests adequately addressed (Kang et al. 2015).

\section{The Theoretical Framework of Corporate Social Responsibility}

The consideration of the objectives and aims of CSR, together with the interests and positions of stakeholders from various perspectives, raises the possibility of analyzing CSR from different points of view, giving rise to different theories that attempt to serve as a framework for the study of CSR. Business ethics justify CSR actions from two main points of view. The first suggests that the company implements its CSR strategy for its own good (Zerbini 2017). From this perspective, CSR is understood as an element in the exchange relations between the company and the stakeholders, where the company generates economic value by promoting the wellbeing of the stakeholders (Kramer and Porter 2002). This first perspective implies that CSR is considered from a strategic point of view with a broader vision than that of exclusively obtaining a result. This is the theoretical perspective that should be considered when dealing with technological advances in relation to CSR.

In the second view, CSR is the consequence of market failures. CSR seeks the benefit of stakeholders even if this means a reduction in the economic performance of the company, to compensate for negligent or harmful actions by the companies that have affected them. In a way, it can be opposed to business benefit and economic efficiency (Zerbini 2017).

Firstly, within the group of explanatory theories of CSR integrated into business strategy, we find the Stakeholder Theory. According to this theory, managers must manage business objectives by reconciling them with the demands and expectations of the main stakeholders, such as consumers, suppliers, the local community, regulators, the environment, and the general public (Madsen and Rodgers 2015; Yasser et al. 2017). The stakeholder theory aims to consider how companies should meet the demands of stakeholders in order to continue to operate and achieve their goals (McKnight and Linnenluecke 2016; Wood 1991). From this perspective, the company must consider not only the interests of the shareholders but those of all those who may have a legitimate interest in the entity (Freeman 1984; Wood 1991). This theory would include all the individuals or groups with which the company interacts, so it is necessary to identify the stakeholders, normally distinguishing between internal and external ones (Brammer and Millington 2003).

Secondly, the Resource and Capability Theory focuses on the idea that competitive advantage does not come from the external environment but is generated internally within the firm (Bonfiglioli et al. 2006). Competitive advantage is defined as the best position that the firm occupies in the market with respect to other entities carrying out the same activity, which allows it to obtain a higher return than its competitors (Guerras-Martín and Navas-López 2015; Sun et al. 2019), and this comes from the company's resources (George et al. 2019; Menguc and Ozanne 2005), which become strategic to the extent that they allow for business results and enable the company to position itself 
advantageously in the market (Branco and Rodrigues 2006; George et al. 2019). In addition, the theory of resources and capacities points out that resources do not generate competitive advantage on their own, but that adequate management is required (Cantrell et al. 2015). Given that the possibility of resources generating competitive advantages depends on capacities, these must also be identified in the company. As each company has its own resources and capacities, the strategies among them will differ (Branco and Rodrigues 2006). In this sense, the theory of resources and capacities has been considered a formal model that explains CSR adopted strategically.

Third, the Signaling Theory suggests that a firm reduces the information asymmetries of external users through signals of different types (Connelly et al. 2011). Thus, the entity, agent, or manager with privileged information (sender) can take actions that signal its ability to meet the needs of another entity or stakeholder, which is not possible to observe otherwise (receiver) (Connelly et al. 2011; Haski-Leventhal and Foot 2016; Moratis 2018). It is composed of two elements, its content, i.e., the information given to the receiver and its sign, i.e., whether the information on that aspect is positive or negative (Luffarelli and Awaysheh 2018). In the area of CSR, the actions taken must be signals from the companies to the stakeholders about their ethical commitment (Connelly et al. 2011; Moratis 2018). The signaling theory analyzes CSR as a business strategy, as it would be a signal given by the company to reveal the responsible nature of the company in the market, which would be valued by the receivers (Connelly et al. 2011; Zerbini 2017). If the signals are considered reliable, they will have an impact on decision-making.

Fourthly, the Social Identity Theory postulates that people identify with other individuals and entities that have similar values to their own and behave according to the expectations of those groups. Furthermore, individuals' belonging to these groups allows them to develop their own identity and even create or improve their self-esteem (Gao and Yang 2016; Alias and Ismail 2015; Schaefer et al. 2019). In summary, this theory states that individuals are more likely to identify with entities with similar values to their own and entities that have a good image and reputation (Alias and Ismail 2015; Gao and Yang 2016). CSR favors linkage with the organization due to the improvement of the image, reputation, and perception of the company (Gao and Yang 2016). This theory explains that individuals may be more likely to identify with companies that carry out CSR practices (Gao and Yang 2016; Schaefer et al. 2019). The theory is applied in the study of the effect of CSR on stakeholders (Gao and Yang 2016; Fosfuri et al. 2011) and assumes that CSR is used strategically (Jones et al. 2017; Rodrigo et al. 2019).

From the perspective of explanatory theories of CSR not integrated into business strategy, but rather to address the market failures that companies cause, we find firstly the Agency Theory that revolves around the principle of maximizing business profit (Amran et al. 2007; Seifert et al. 2003). This theory postulates that the interests of principals (in this case, shareholders or owners) and agents (in this case, managers who make decisions about CSR) are conflicting and opposed (Amran et al. 2007; Wang and Coffey 1992). This is based on a negative image of human behavior by assuming that, in relationships, the actors involved only seek to maximize their usefulness and are willing to deceive the other party in order to achieve their own goals (Aßländer et al. 2016). Agency costs, which would be all those costs incurred by the company in order to align the interests of the agent and the principal (Jensen and Meckling 1976), are defined as the sum of supervision or control costs on the part of the principal, guarantee costs, and residual loss.

Secondly, the Stewardship Theory proposes that managers not only act to maximize their usefulness, but also seek recognition, satisfaction with satisfactory results, respect for authority, professional ethics (Muth and Donaldson 1998), value creation, and attention to social and environmental demands (Aßländer et al. 2016). As for the position towards CSR initiatives, from this theoretical approach, it is thought that they are not efficient for the company, but neither are they motivated by the search for their own profits by the managers (Zerbini 2017).

Third, Institutional Theory predicts the impact on social and economic actors of factors located at the institutional level such as systemic norms and beliefs, economic development, and other factors at 
the regional or national level (Maas and Liket 2011). Institutions are the set of societal norms that limit human interaction and are necessary to protect the rights of these economic agents (North 1990), so that their absence or malfunctioning prevents or creates barriers to economic activity (Aracil 2019). Thus, according to institutional theory, companies with their behavior do not seek efficiency, but rather, survive and operate in the market (Zerbini 2017). By adapting to the institutional environment, the company gains/maintains its legitimacy, obtains resources, has stability, and ensures its sustainability over time (Shawkat et al. 2019). Companies would carry out social and environmental initiatives in response to their institutional environment that reflects expectations about the organization's behavior (Zerbini 2017).

Finally and fourthly, the Legitimacy Theory postulates that organizations develop their activity in accordance with what is desired and expected by the community, acting in accordance with these expectations as if it were a system of rules (Zyznarska-Dworczak 2018). In exchange for this compliance, the company is allowed to operate in the market by obtaining the so-called "social license" and obtain the necessary resources to develop its activity (Chelli et al. 2014). The organizations ensure that society in general and interest groups in particular observe their actions as legitimate (Suchman 1995). To this end, companies change their behavior to ensure that it is in line with social expectations and is perceived as correct (Beske-Janssen et al. 2019). CSR and its communication would be the result of the company's interaction with its internal and external environment in its search to obtain and maintain its legitimacy or correct the lack of it (Jamali 2008; Mäkelä and Näsi 2010; Zyznarska-Dworczak 2018). Through CSR reports, companies would try to show that the social, ecological, and economic impact of their operations is in line with the set of norms and values of society (Beske-Janssen et al. 2019).

\section{Method}

\subsection{Scope of the Review}

The review of previous studies has provided a broad perspective on the evolution of CSR, its importance in business, the literature, and its future development.

The review was conducted after a search of relevant research published to date and the results obtained were then filtered to organize the information. The articles were evaluated to obtain a base of information that would contribute to the field of study. In general, the literature was selected or discarded based on keywords. Therefore, non-item related papers were discarded (Garde-Sanchez et al. 2018). Papers were then classified by year, author, and topic. The review of the concepts used, ideas, reflections, and discussions of the documents analyzed allowed the identification of key studies, lines of research, and future trends. At this stage, measures of the quantity of citations and quality of publications served as guidance (Baumann et al. 2002; Kitchenham Barbara et al. 2009).

\subsection{Screening Process}

The first stage was to define the objective to be achieved by the review, i.e., the evolution of CSR - in the literature, in companies_objectives, and theoretical frameworks. Then, we conducted a search in several Web of Science (WOS) bibliographic databases, using predefined keywords. In this consultation, we focused on the evaluation of articles with international impact. The selected journals were all listed in the Journal Citation Index (JCR), Social Sciences Citation Index (SSCI), and/or Scopus, which contain a large number of academic journals covering different fields of knowledge. Some books were included in our analysis according to their suitability for the item of study. We excluded symposia and doctoral theses since, if they are of good quality, they are also published in journal articles.

In the search carried out, the key words included in the search were CSR, Business Ethics, Environmental strategies, Stakeholders, Social and Community Commitment, and Sustainability. Due to the aim of the research, to analyze the origin and evolution of CSR in order to identify trends and lines of research, the time horizon was not limited. However, it was only from 1990 onwards that a significant number of articles on this subject began to be published in high impact journals. 
Moreover, in each year, we focused on the most cited articles. The articles were filtered by thematic areas, selecting those belonging to the Social Science area and within this, Business, Management, and Finance and Accounting.

Several approaches were used in extracting the articles for analysis: first, a sweep was made of the keywords. Then, special attention was paid to the titles of all articles in each volume, as well as to those of the abstracts (Legge and Devore 1987; Pina Martínez and Pradas 1995). If these methods were not sufficient or if any doubt remained, we proceeded to read the full article, which was necessary to extract the historical evolution of CSR.

Finally, each article was analyzed to identify the objective of the research, the issues considered, the background, the theoretical framework, the methodology, the results obtained, the conclusions drawn, and the proposed future research. The data generated during this search were organized in an Excel database. A total of 278 articles on CSR were obtained.

\section{Conclusions}

Corporate Social Responsibility, which was initially criticized and considered a policy in conflict with the objectives of the company by those authors who defended the maximization of profit as the sole business responsibility, was gradually integrated with other actions until it was considered, from the first decade of the 2000s, as a strategic element integrated, along with the rest of the business strategies, into the core of the business (Lee 2008; Porter and Kramer 2006), although the objective of social legitimacy is still present in many entities, as a response to counteract, sometimes, negligent or damaging actions.

It should be added that the integration of CSR into business strategy not only responds to commitments to social agents, but also analyzes its possible positive effect on financial performance indicators, due to improved employees motivation, the ability to attract talent, improved resource management, competitiveness or reliability in the company, among other aspects (Kao et al. 2018). Companies must consider, along with obtaining profits, that their decision-making responds to ethical standards that satisfy all the agents with which the company interacts, with care for the environment occupying a preferential place due to greater sensitivity to this issue in society in general, as well as institutional interest, specified in the sustainable development objectives of the 2030 agenda (Teixeira et al. 2018).

Companies are increasingly aware of the need to be sustainable not only from a financial point of view, but also from a social and environmental one, for which they must develop a proactive action towards society, respecting the sustainability of resources and the environment, an issue related to the progress made in topics such as eco-innovation (Galvão et al. 2019). From this perspective, the aim is for CSR to respond adequately to the challenges and social demands of the stakeholders that affect and are affected by the entity, since the sustainability of the company over time depends on it (Carroll and Shabana 2010; Yin and Jamali 2016).

Finally, we may conclude that CSR advocates that the success of an organization depends on its economic gains, environmental sustainability, as well as its social results, i.e., the management of the "triple bottom line" (Zadek et al. 2003), and should be integrated into the organization's strategy (Siegel and Vitaliano 2007). In short, the instrumental use of CSR has given way to its consideration as a strategy in interaction with others with the aim of achieving long-term sustainability and meeting the legitimate requirements of the various stakeholders.

The literature review highlights missing links that may provide future plausible directions for CSR research. As discussed throughout this paper and as reflected in the research (Carroll and Shabana 2010; Lee 2008), the concept of CSR has evolved to the present day, where it is considered as a strategic element, together with the other strategies of the company. Its analysis requires integrated thinking that takes into account the complexity of business decisions, where the various policies are integrated into the objective of long-term sustainability. It is necessary to develop tools that reflect the interrelationships between different business strategies. It also requires the development of sustainability measures. 
This idea leads us to delimit, as a line of CSR research, the analysis of business strategies that are related to each other, among which the relationship between CSR and innovation could stand out, and to analyze the effects on both financial and non-financial performance indicators, being necessary to define them previously. Much progress has been made in the analysis of financial indicators, but the field of non-financial performance indicators is still quite unexplored.

On the other hand, in recent years, there has been an increase in indicators in the various areas of CSR that will enable a more in-depth analysis of both social, environmental, and economic areas, as well as the measurement of CSR constructs. This will make it possible to perceive CSR performance as a broad assessment and not as isolated issues of the company with respect to social or environmental issues. To the extent that these constructs are widely accepted, comparable analyses can be carried out by academia.

These more complex measurements will enable another line of research focused on stakeholders. Studies are needed that analyze how stakeholders as a whole are affected. Studies have been carried out in which the effect of certain CSR policies on one of the stakeholders is analyzed, but it is necessary to develop studies in which the impact of the policies on employees, consumers, owners, the community, and the environment is taken into account jointly (Setó and Rabassa 2007). Additionally, and in relation to stakeholders, it is a relevant area of research to determine to what extent their demands and requirements are related to CSR. The literature has analyzed in depth how governance mechanisms determine CSR strategies, but as communication channels are expanded and improved, it is important to determine the extent to which stakeholders affect the company's CSR strategy. CSR policies must be broad and extensive, that is, they must capture all the important aspects or dimensions of the relations between the company and its stakeholders and this constitutes a relevant line of research, which will serve to have a global vision of CSR strategies.

In short, the evolution of CSR objectives opens up new fields of research, the results of which will provide management tools for companies, enabling the advancement of this area of science and its practical application in the business world.

Author Contributions: S.R.-G., M.L.A.-C. and M.V.L.-P. have done the detailed literature review and was involved in developing the methodology of the research. They was also responsible for interpretation of the results and writing the paper based on them. This paper is developed under the constant supervision of L.R.-A. All authors have read and agreed to the published version of the manuscript.

Funding: R\&D Projects. European Regional Development Fund (ERDF) Andalusia 2014- 2020 Operational Program, Grant/Award Number: B1-SEJ-387-UGR18.

Conflicts of Interest: The authors declare no conflict of interest.

\section{References}

Abrams, Frank W. 1951. Management's responsibilities in a complex world. Harvard Business Review 29: 29-34.

Adams, Richard, Sally Jeanrenaud, John Bessant, David Denyer, and Patrick Overy. 2016. Sustainability-oriented innovation: A systematic review. International Journal of Management Reviews 18: 180-205. [CrossRef]

Alias, Siti. N., and Maimunah Ismail. 2015. Antecedents of philanthropic behavior of health care volunteers. European Journal of Training and Development 39: 277-97. [CrossRef]

Amin-Chaudhry, Anjum. 2016. Corporate social responsibility-from a mere concept to an expected business practice. Social Responsibility Journal 12: 190-207. [CrossRef]

Amran, Azlan B., Lim L. Ling, and Yahya Sofri. 2007. A study of corporate philanthropic traits among major Malaysian corporations. Social Responsibility Journal 3: 21-30. [CrossRef]

Aracil, Elisa. 2019. Corporate social responsibility of Islamic and conventional banks. International Journal of Emerging Markets 14: 582-600. [CrossRef]

Arco-Castro, Lourdes, María Victoria López-Pérez, María del Carmen Pérez-López, and Lázaro Rodríguez-Ariza. 2020. How market value relates to corporate philanthropy and its assurance. The moderating effect of the business sector. Business Ethics: A European Review 29: 266-81. [CrossRef]

Arlow, Peter. 1991. Personal characteristics in college students' evaluations of business ethics and corporate social responsibility. Journal of Business Ethics 10: 63-69. [CrossRef] 
Ashrafi, Mehrnaz, Michelle Adams, Tony R. Walker, and Greg Magnan. 2018. How corporate social responsibility can be integrated into corporate sustainability: A theoretical review of their relationships. International Journal of Sustainable Development \& World Ecology 25: 672-82.

Aßländer, Michael S., Julia Roloff, and Dilek Zamantili Nayır. 2016. Suppliers as stewards? Managing social standards in first-and second-tier suppliers. Journal of Business Ethics 139: 661-83. [CrossRef]

Aupperle, Kenneth E., Archie B. Carroll, and John D. Hatfield. 1985. An empirical examination of the relationship between corporate social responsibility and profitability. Academy of Management Journal 28: 446-63.

Bae, Seong M., Md. Abdul K. Masud, and John D. Kim. 2018. A cross-country investigation of corporate governance and corporate sustainability disclosure: A signaling theory perspective. Sustainability 10: 2611. [CrossRef]

Bagire, Vicent A., Inmaculate Tusiime, Grace Nalweyiso, and John B. Kakooza. 2011. Contextual environment and stakeholder perception of corporate social responsibility practices in Uganda. Corporate Social Responsibility and Environmental Management 18: 102-9. [CrossRef]

Banks, Louis. 1975. The Mission of Our Business Society. Harvard Business Review 53: 57-65.

Barnard, Chester. 1938. The Functions of the Executive. Cambridge: Harvard University Press.

Baumann, Henrikke, Frank Boons, and Annica Bragd. 2002. Mapping the green product development field: Engineering, policy and business perspectives. Journal of Cleaner Production 10: 409-25. [CrossRef]

Beske-Janssen, Philip, Stefan Schaltegger, and Sonja Liedke. 2019. Performance measurement in sustainable supply chain management: Linking research and practice. In Handbook on the Sustainable Supply Chain. Cheltenham: Edward Elgar Publishing, pp. 331-56.

Bhaduri, Saumitra N., and Ekta Selarka. 2016. Corporate Social Responsibility Around the World: An Overview of Theoretical Framework, and Evolution. In Corporate Governance and Corporate Social Responsibility of Indian Companies. Singapore: Springer, pp. 11-32.

Bocken, Nancy, Julian M. Allwood, A. R. Willey, and Henry King. 2011. Development of an eco-ideation tool to identify stepwise greenhouse gas emissions reduction options for consumer goods. Journal of Cleaner Production 19: 1279-87. [CrossRef]

Bonfiglioli, Elena, Moir Lance, and Véronique Ambrosini. 2006. Developing the wider role of business in society: The experience of Microsoft in developing training and supporting employability. Corporate Governance: The International Journal of Business in Society 6: 401-8. [CrossRef]

Bouslah, Kais, Lawrence Kryzanowski, and Bouchra M'Zali. 2018. Social performance and firm risk: Impact of the financial crisis. Journal of Business Ethics 149: 643-69. [CrossRef]

Bowen, Howard R. 1953. Social Responsibility of the Businessman. New York: Harper \& Row.

Brammer, Stephen, and Andrew Millington. 2003. The effect of stakeholder preferences, organizational structure and industry type on corporate community involvement. Journal of Business Ethics 45: 213-26. [CrossRef]

Branco, Manuel Castelo, and Lúcia Lima Rodrigues. 2006. Corporate social responsibility and resource-based perspectives. Journal of Business Ethics 69: 111-32. [CrossRef]

Brogi, Marina, and Valentina Lagasio. 2019. Environmental, social, and governance and company profitability: Are financial intermediaries different? Corporate Social Responsibility and Environmental Management 26: 576-87.

Brønn, Peggy S., and Deborah Vidaver-Cohen. 2009. Corporate motives for social initiative: Legitimacy, sustainability, or the bottom line? Journal of Business Ethics 87: 91-109. [CrossRef]

Brower, Jacob, Saim Kashmiri, and Vijai Mahajan. 2017. Signaling virtue: Does firm corporate social performance trajectory moderate the social performance-financial performance relationship? Journal of Business Research 81: 86-95. [CrossRef]

Cantrell, John E., Elias Kyriazis, and Gary Noble. 2015. Developing CSR giving as a dynamic capability for salient stakeholder management. Journal of Business Ethics 130: 403-21. [CrossRef]

Carroll, Archie B. 1991. The pyramid of corporate social responsibility: Toward the moral management of organizational stakeholders. Business Horizons 34: 39-48. [CrossRef]

Carroll, Archie B. 1999. Corporate social responsibility: Evolution of a definitional construct. Business $\mathcal{E}$ Society 38: 268-95.

Carroll, Archie B. 2008. A history of corporate social responsibility: Concepts and practices. In The Oxford Handbook of Corporate Social Responsibility. Oxford: Oxford University Press, pp. 19-46. 
Carroll, Archie B., and Kareem M. Shabana. 2010. The business case for corporate social responsibility: A review of concepts, research and practice. International Journal of Management Reviews 12: 85-105. [CrossRef]

Chang, Ching-Hsun. 2011. The influence of corporate environmental ethics on competitive advantage: The mediation role of green innovation. Journal of Business Ethics 104: 361-70. [CrossRef]

Chelli, Mohamed, Sylvain Durocher, and Jacques Richard. 2014. France's new economic regulations: Insights from institutional legitimacy theory. Accounting, Auditing \& Accountability Journal 27: 283-316.

Chowdhury, Reza H., Sungchul Choi, Simon Ennis, and Dongseop Chung. 2019. Which Dimension of Corporate Social Responsibility is a Value Driver in the Oil and Gas Industry? Canadian Journal of Administrative Sciences/Revue Canadienne des Sciences de l'Administration 36: 260-72. [CrossRef]

Closon, Caroline, Christophe Leys, and Catherine Hellemans. 2015. Perceptions of corporate social responsibility, organizational commitment and job satisfaction. Management Research: The Journal of the Iberoamerican Academy of Management 13: 31-54. [CrossRef]

Cochran, Philip L., and Robert A. Wood. 1984. Corporate social responsibility and financial performance. Academy of Management Journal 27: 42-56.

Connelly, Brian L., Trevis Certo, R. Duane Ireland, and Christopher R. Reutzel. 2011. Signaling Theory: A Review and Assessment. Journal of Management 37: 39-67. [CrossRef]

Cornelius, Neraline J., James Wallace, and Rana Tassabehji. 2007. An analysis of Corporate Social Responsibility, Corporate Identity and Ethics Teaching in Business School. Journal of Business Ethics 76: 117-35. [CrossRef]

Cupertino, Sebastiano, Costanza Consolandi, and Alessandro Vercelli. 2019. Corporate social performance, financialization, and real Investment in US manufacturing firms. Sustainability 11: 1836. [CrossRef]

Dahlsrud, Alexander. 2008. How corporate social responsibility is defined: An analysis of 37 definitions. Corporate Social Responsibility and Environmental Management 15: 1-13. [CrossRef]

Davis, Keith. 1973. The case for and against business assumption of social responsibilities. Academy of Management Journal 16: 312-22.

Degie, Bruck, and Wassie Kebede. 2019. Corporate social responsibility and its prospect for community development in Ethiopia. International Social Work 62: 376-89. [CrossRef]

del Mar Miras-Rodríguez, María, Amalia Carrasco-Gallego, and Bernabé Escobar-Pérez. 2013. Are socially responsible behaviors paid off equally? A Cross-cultural analysis. Corporate Social Responsibility and Environmental Management 22: 237-56.

del Mar Miras-Rodríguez, María, Amalia Carrasco-Gallego, and Bernabé Escobar-Pérez. 2014. Has the CSR engagement of electrical companies had an effect on their performance? A closer look at the environment. Business Strategy and the Environment 24: 819-35. [CrossRef]

Dey, Prasanta K., Nikolaos Petridis, Konstantinos Petridis, Chrisovalantis Malesios, Jonathan D. Nixon, and Kumar Ghosh. 2018. Environmental management and corporate social responsibility practices of small and medium-sized enterprises. Journal of Cleaner Production 195: 687-702. [CrossRef]

Donaldson, Thomas, and Thomas W. Dunfee. 1994. Toward a unified conception of business ethics: Integrative social contracts theory. Academy of Management Review 19: 252-84. [CrossRef]

Dyllick, Thomas, and Katrin Muff. 2016. Clarifying the meaning of sustainable business: Introducing a typology from business-as-usual to true business sustainability. Organization \& Environment 29: 156-74.

Epstein, Edwin M. 1976. The social role of business enterprise in Britain: An American perspective: Part I. Journal of Management Studies 13: 213-33. [CrossRef]

Epstein, Edwin M. 1987. The corporate social policy process: Beyond business ethics, corporate social responsibility, and corporate social responsiveness. California Management Review 29: 99-114. [CrossRef]

Fernández-Guadaño, Josefina, and Jesús H. Sarria-Pedroza. 2018. Impact of corporate social responsibility on value creation from a stakeholder perspective. Sustainability 10: 2062. [CrossRef]

Fisher, Kyla, Jessica Geenen, Marie Jurcevic, Katya McClintock, and Glynn Davis. 2009. Applying asset-based community development as a strategy for CSR: A Canadian perspective on a win-win for stakeholders and SMEs. Business Ethics: A European Review 18: 66-82. [CrossRef]

Flammer, Caroline. 2018. Competing for government procurement contracts: The role of corporate social responsibility. Strategic Management Journal 39: 1299-324. [CrossRef]

Ford, Robert C., and Woodrow D. Richardson. 1994. Ethical decision making: A review of the empirical literature. Journal of Business Ethics 13: 205-21. [CrossRef] 
Fosfuri, Andrea, Marco S. Giarratana, and Esther Roca. 2011. Community-focused strategies. Strategic Organization 9: 222-39. [CrossRef]

Frederick, William C. 2016. Commentary corporate social responsibility: Deep roots, flourishing growth, promising future. Frontiers in Psychology 7: 129. [CrossRef] [PubMed]

Freeman, R. Edward. 1984. Strategic management: Strategic management: A stakeholder approach. B. The politics of stakeholder theory: Some future directions. Business Ethics Quarterly 4: 409-21. [CrossRef]

Friedman, Milton. 1962. Capitalism and Freedom. Chicago: University of Chicago Press.

Friedman, Milton. 1970. A theoretical framework for monetary analysis. Journal of Political Economy 78: 193-238. [CrossRef]

Gallego-Álvarez, Isabel, José Manuel Prado-Lorenzo, and Isabel-María García-Sánchez. 2011. Corporate social responsibility and innovation: A resource-based theory. Management Decision 49: 1709-27. [CrossRef]

Galvão, Anderson, Luis Mendes, Carla Marques, and Carla Mascarenhas. 2019. Factors influencing students' corporate social responsibility orientation in higher education. Journal of Cleaner Production 215: 290-304. [CrossRef]

Gao, Yongqiang, and Haibin Yang. 2016. Do employees support corporate philanthropy? Evidence from Chinese listed companies. Management and Organization Review 12: 747-68. [CrossRef]

García-Sánchez, Isabel-María, and Cristina-Andrea Araújo-Bernardo. 2020. What colour is the corporate social responsibility report? Structural visual rhetoric, impression management strategies, and stakeholder engagement. Corporate Social Responsibility and Environmental Management 27: 1117-42. [CrossRef]

Garde-Sanchez, Raquel, María Victoria López-Pérez, and Antonio M. López-Hernández. 2018. Current trends in research on social responsibility in state-owned enterprises: A review of the literature from 2000 to 2017. Sustainability 10: 2403. [CrossRef]

Geissdoerfer, Martin, Nancy M. P. Bocken, and Erik Jan Hultink. 2016. Design thinking to enhance the sustainable business modelling process-A workshop based on a value mapping process. Journal of Cleaner Production 135: 1218-32. [CrossRef]

George, Jordana J., Jie Yan, and Dorothy E. Leidner. 2019. Data philanthropy: Corporate responsibility with strategic value? Information Systems Management 37: 186-97. [CrossRef]

Godfrey, Paul C., Craig B. Merrill, and Jared M. Hansen. 2009. The relationship between corporate social responsibility and shareholder value: An empirical test of the risk management hypothesis. Strategic Management Journal 30: 425-45. [CrossRef]

Gomez-Carrasco, Pablo, Encarna Guillamon-Saorin, and Beatriz Garcia Osma. 2016. The illusion of CSR: Drawing the line between core and supplementary CSR. Sustainability Accounting, Management and Policy Journal 7: 125-51. [CrossRef]

González-Ramos, María I., Mario J. Donate, and Fátima Guadamillas. 2014. Technological posture and corporate social responsibility: Effect on innovation performance. Environmental Engineering $\mathcal{E}$ Management Journal 13: 2497-505.

Guerras-Martín, Luis Á., and José E. Navas-López. 2015. La dirección estratégica de la empresa: Teoría y aplicaciones. Pamplona: Thomson Reuters Civitas.

Halkos, George, and Antonis Skouloudis. 2018. Corporate social responsibility and innovative capacity: Intersection in a macro-level perspective. Journal of Cleaner Production 182: 291-300. [CrossRef]

Hameed, Imran, Zahid Riaz, Ghulam A. Arain, and Omer Farooq. 2016. How do internal and external CSR affect employees' organizational identification? A perspective from the group engagement model. Frontiers in Psychology 7: 788. [CrossRef]

Harjoto, Maretno A., and Jim Salas. 2017. Strategic and institutional sustainability: Corporate social responsibility, brand value, and Interbrand listing. Journal of Product \& Brand Management 26: 545-58.

Haski-Leventhal, Debbie, and Christine Foot. 2016. The relationship between disclosure and household donations to nonprofit organizations in Australia. Nonprofit and Voluntary Sector Quarterly 45: 992-1012. [CrossRef]

Havlová, Kristyna. 2015. What integrated reporting changed: The case study of early adopters. Procedia Economics and Finance 34: 231-37. [CrossRef]

Hetherington, John A. C. 1969. Fact and legal theory: Shareholders, managers, and corporate social responsibility. Stanford Law Review 248: 258-83. [CrossRef] 
Hsieh, Jasper, Kerry P. Curtis, and Anne W. Smith. 2008. Implications of stakeholder concept and market orientation in the US nonprofit arts context. International Review on Public and Nonprofit Marketing 5: 1-13. [CrossRef]

$\mathrm{Hu}$, Baoliang, Tao Zhang, and Shuai Yan. 2020. How corporate social responsibility influences business model innovation: The mediating role of organizational legitimacy. Sustainability 12: 2667. [CrossRef]

Jamali, Dima. 2008. A stakeholder approach to corporate social responsibility: A fresh perspective into theory and practice. Journal of Business Ethics 82: 213-31. [CrossRef]

Jenkins, Rhys. 2009. Corporate Social Responsibility. In Handbook of Economics and Ethics. Edited by Jan Peil and Irene van Staveren. Massachusetts: Edward Elgar Publishing, Inc., pp. 69-77.

Jensen, Michael C., and William H. Meckling. 1976. Theory of the firm: Managerial behavior, agency costs and ownership structure. Journal of Finance Economics 3: 305-60. [CrossRef]

Jones, Thomas M. 1980. Corporate social responsibility revisited, redefined. California Management Review 22: 59-67. [CrossRef]

Jones, David A., Chelsea R. Willness, and Ante Glavas. 2017. When corporate social responsibility (CSR) meets organizational psychology: New frontiers in microCSR research and fulfilling a quid pro quo through multilevel insights. Frontiers in Psychology 8: 1-14. [CrossRef]

Kalkanci, Başak, Morvarid Rahmani, and L. Beril Toktay. 2019. The role of inclusive innovation in promoting social sustainability. Production and Operations Management 28: 2960-82. [CrossRef]

Kang, Jin-Su, Chun-Fang Chiang, Kitipop Huangthanapan, and Stephen Downing. 2015. Corporate social responsibility and sustainability balanced scorecard: The case study of family-owned hotels. International Journal of Hospitality Management 48: 124-34. [CrossRef]

Kao, Erin H., Chih-Chuan Yeh, Li-Hsun Wang, and Hung-Gay Fung. 2018. The relationship between CSR and performance: Evidence in China. Pacific-Basin Finance Journal 51: 155-70. [CrossRef]

Kennedy, Ellen J., and Leigh Lawton. 1998. Religiousness and business ethics. Journal of Business Ethics 17: 163-75. [CrossRef]

Kim, Minseok, Boyoung Kim, and Sungho Oh. 2018. Relational benefit on satisfaction and durability in strategic corporate social responsibility. Sustainability 10: 1104. [CrossRef]

Kim, Dae-Young, Sung-Bum Kim, and Kathleen J. Kim. 2019. Building corporate reputation, overcoming consumer skepticism, and establishing trust: Choosing the right message types and social causes in the restaurant industry. Service Business 13: 363-88. [CrossRef]

Kitchenham Barbara, O. Pearl Brereton, David Budgen, Mark Turner, John Bailey, and Stephen Linkman. 2009. Systematic literature reviews in software engineering: A systematic literature review. Information and Software Technology 51: 7-15. [CrossRef]

Kolodinsky, Robert W., Timothy Madden, Daniel Zisk, and Eric Henkel. 2010. Attitudes about corporate social responsibility: Business student predictors. Journal of Business Ethics 91: 167-81. [CrossRef]

Kramer, Mark R., and Michael E. Porter. 2002. La ventaja competitiva de la filantropía corporativa. Harvard Business Review 80: 49-62.

Lee, Min-Dong P. 2008. A review of the theories of corporate social responsibility: Its evolutionary path and the road ahead. International Journal of Management Reviews 10: 53-73. [CrossRef]

Legge, Jerome S., Jr., and James Devore. 1987. Measuring productivity in US public administration and public affairs programs 1981-1985. Administration \& Society 19: 147-56.

Li, Xiao. 2020. The effectiveness of internal control and innovation performance: An intermediary effect based on corporate social responsibility. PLoS ONE 15: e0234506. [CrossRef]

Lins, Karl V., Henri Servaes, and Ane Tamayo. 2017. Social capital, trust, and firm performance: The value of corporate social responsibility during the financial crisis. The Journal of Finance 72: 1785-824. [CrossRef]

Lister, Jane. 2018. The policy role of corporate carbon management: Co-regulating ecological effectiveness. Global Policy 9: 538-48. [CrossRef]

Lock, Irina, and Charlotte Schulz-Knappe. 2019. Credible corporate social responsibility (CSR) communication predicts legitimacy: Evidence from an experimental study. Corporate Communications: An International Journal 24: 2-20. [CrossRef]

Lu, Jintao, Licheng Ren, Wenfang Lin, Yifan He, and Justas Streimikis. 2019. Policies to promote corporate social responsibility (CSR) and assessment of CSR impacts. Business Administration and Management 22: 82-98. [CrossRef] 
Luffarelli, Jonathan, and Amrou Awaysheh. 2018. The impact of indirect corporate social performance signals on firm value: Evidence from an event study. Corporate Social Responsibility and Environmental Management 25: 295-310.

Luo, Xueming, and Chitra B. Bhattacharya. 2009. The debate over doing good: Corporate social performance, strategic marketing levers, and firm-idiosyncratic risk. Journal of Marketing 73: 198-213. [CrossRef]

Luo, Xueming, and Shuili Du. 2015. Exploring the relationship between corporate social responsibility and firm innovation. Marketing Letters 26: 703-14. [CrossRef]

Maas, Karen, and Kellie Liket. 2011. Talk the walk: Measuring the impact of strategic philanthropy. Journal of Business Ethics 100: 445-64. [CrossRef]

Maclagan, Patrick. 2008. Organizations and responsibility: A critical overview. Systems Research and Behavioral Science: The Official Journal of the International Federation for Systems Research 25: 371-81. [CrossRef]

Madsen, Peter M., and Zachariah J. Rodgers. 2015. Looking good by doing good: The antecedents and consequences of stakeholder attention to corporate disaster relief. Strategic Management Journal 36: 776-94. [CrossRef]

Mäkelä, Hannele, and Salme Näsi. 2010. Social responsibilities of MNCs in downsizing operations: A Finnish forest sector case analysed from the stakeholder, social contract and legitimacy theory point of view. Accounting, Auditing and Accountability Journal 23: 149-74.

Margolis, Joshua D., and James P. Walsh. 2003. Misery loves companies: Rethinking social initiatives by business. Administrative Science Quarterly 48: 268-305. [CrossRef]

Marí-Farinós, Jesús. 2017. Sustainability as an object of corporate social responsibility. VITRUVIO-International Journal of Architectural Technology and Sustainability 2: 13-22. [CrossRef]

Martínez-Conesa, Isabel, Pedro Soto-Acosta, and Mercedes Palacios-Manzano. 2017. Corporate social responsibility and its effect on innovation and firm performance: An empirical research in SMEs. Journal of Cleaner Production 142: 2374-83. [CrossRef]

McGuire, Joseph W. 1963. Business and Society. New York: McGraw-Hill.

McGuire, Jean B., Alison Sundgren, and Thomas Schneeweis. 1988. Corporate social responsibility and firm financial performance. Academy of Management Journal 31: 854-72.

McKnight, Brent, and Martina K. Linnenluecke. 2016. How firm responses to natural disasters strengthen community resilience: A stakeholder-based perspective. Organization E Environment 29: 290-307.

McWilliams, Abagail, Donald S. Siegel, and Patrick M. Wright. 2006. Corporate social responsibility: Strategic implications. Journal of Management Studies 43: 1-18. [CrossRef]

Menguc, Bulent, and Lucie K. Ozanne. 2005. Challenges of the "green imperative": A natural resource-based approach to the environmental orientation-business performance relationship. Journal of Business Research 58: 430-38. [CrossRef]

Moratis, Lars. 2018. Signaling responsibility? Applying signaling theory to the ISO 26000 standard for social responsibility. Sustainability 10: 4172. [CrossRef]

Muth, Melinda, and Lex Donaldson. 1998. Stewardship theory and board structure: A contingency approach. Corporate Governance: An International Review 6: 5-28. [CrossRef]

Nazzaro, Concetta, Marcello Stanco, and Giuseppe Marotta. 2020. The Life Cycle of Corporate Social Responsibility in Agri-Food: Value Creation Models. Sustainability 12: 1287. [CrossRef]

North, Douglass. 1990. Institutional, institutional Change and Economic Performance. New York: Cambridge University Press.

O'Riordan, Linda, and Jenny Fairbrass. 2014. Managing CSR stakeholder engagement: A new conceptual framework. Journal of Business Ethics 125: 121-45. [CrossRef]

Orlitzky, Marc. 2011. Institutional logics in the study of organizations: The social construction of the relationship between corporate social and financial performance. Business Ethics Quarterly 21: 409-44. [CrossRef]

Orlitzky, Marc, Frank L. Schmidt, and Sara L. Rynes. 2003. Corporate social and financial performance: A meta-analysis. Organization Studies 24: 403-41. [CrossRef]

Panait, Mirela, Marian Catalin Voica, and Irina Radulescu. 2014. The Activity of Capital Market's Actors: Under the Sign of Social Responsibility. Procedia Economics and Finance 8: 522-28. [CrossRef]

Park, Jong-Chull, Prashant Mool, June-Hee Naa, and Chang-Gon Lee. 2014. The Effects of Creating Shared Value on Corporate Performance. Journal of Distribution Science 12: 29-35. [CrossRef] 
Pina Martínez, Vicente, and Lourdes Torres Pradas. 1995. Evaluación del rendimiento de los departamentos de contabilidad de las universidades españolas. Hacienda Pública Española 135: 183-90.

Pirnea, Ionela C., Marieta Olaru, and Cristina Moisa. 2011. Relationship between corporate social responsibility and social sustainability. Economy Transdisciplinarity Cognition 14: 36-43.

Porter, Michael E., and Mark R. Kramer. 2006. The link between competitive advantage and corporate social responsibility. Harvard Business Review 84: 78-92.

Quinn, John J. 1997. Personal ethics and business ethics: The ethical attitudes of owner/managers of small business. Journal of Business Ethics 16: 119-27. [CrossRef]

Rexhepi, Gadaf, Selma Kurtishi, and Gjilnaipe Bexheti. 2013. Corporate social responsibility (CSR) and innovation the drivers of business growth. Procedia-Social and Behavioral Sciences 75: 532-41. [CrossRef]

Robertson, Diana C. 1993. Empiricism in business ethics: Suggested research directions. Journal of Business Ethics 12: 585-99. [CrossRef]

Rodrigo, Pablo, Claudio Aqueveque, and Ignacio J. Duran. 2019. Do employees value strategic CSR? A tale of affective organizational commitment and its underlying mechanisms. Business Ethics: A European Review 28: 459-75. [CrossRef]

Rost, Katja, and Thomas Ehrmann. 2017. Reporting biases in empirical management research: The example of win-win corporate social responsibility. Business $\mathcal{E}$ Society 56: 840-88.

Rothenhoefer, Lisa M. 2019. The impact of CSR on corporate reputation perceptions of the public-A configurational multi-time, multi-source perspective. Business Ethics: A European Review 28: 141-55. [CrossRef]

Saiia, David H., Archie B. Carroll, and Ann K. Buchholtz. 2003. Philanthropy as strategy: When corporate charity "begins at home". Business E Society 42: 169-201.

Salvioli, Fabian O. 2000. Los derechos Humanos en las convenciones internacionales de la última década del Siglo XX. In Las grandes conferencias Mundiales de la década de los 90. Programa de las Naciones Unidas para el Desarrollo, Tomo I. La Plata: IRI, pp. 11-81.

Santos, Rita, Ronald Wennersten, Eduardo B. Oliva, and Walter Leal Filho. 2009. Strategies for competitiveness and sustainability: Adaptation of a Brazilian subsidiary of a Swedish multinational corporation. Journal of Environmental Management 90: 3708-16. [CrossRef] [PubMed]

Schaefer, Sarah D., Ralf Terlutter, and Sandra Diehl. 2019. Is my company really doing good? Factors influencing employees' evaluation of the authenticity of their company's corporate social responsibility engagement. Journal of Business Research 101: 128-43. [CrossRef]

Schönherr, Norma, Florian Findler, and André Martinuzzi. 2017. Exploring the interface of CSR and the Sustainable Development Goals. Transnational Corporations 24: 33-47. [CrossRef]

Seifert, Bruce, Sara A. Morris, and Barbara R. Bartkus. 2003. Comparing big givers and small givers: Financial correlates of corporate philanthropy. Journal of Business Ethics 45: 195-211. [CrossRef]

Setó, Dolors, and Noemí Rabassa. 2007. Responsabilidad social corporativa: Reflexiones sobre futuras líneas de investigación. In El comportamiento de la empresa ante entornos dinámicos: XIX Congreso anual y XV Congreso Hispano Francés de AEDEM. Vitoria: Asociación Española de Dirección y Economía de la Empresa.

Shahzad, Mohsin, Ying Qu, Saad Ahmed Javed, Abaid Ullah Zafar, and Saif Ur Rehman. 2020. Relation of environment sustainability to CSR and green innovation: A case of Pakistani manufacturing industry. Journal of Cleaner Production 253: 119938. [CrossRef]

Shawkat, Talha, Shahid Habib, and Shahzad Ahmed Khan. 2019. Socially Responsible Identity: Linking Corporate Social Responsibility, Strategic Implementation and Quality Performance. Pakistan Business Review 20: 612-25.

Shnayder, Larissa, and Frank J. Van Rijnsoever. 2018. How expected outcomes, stakeholders, and institutions influence corporate social responsibility at different levels of large basic needs firms. Business Strategy and the Environment 27: 1689-707. [CrossRef]

Shnayder, Larissa, Frank J. Van Rijnsoever, and Marko P. Hekkert. 2016. Motivations for Corporate Social Responsibility in the packaged food industry: An institutional and stakeholder management perspective. Journal of Cleaner Production 122: 212-27. [CrossRef]

Siegel, Donald S., and Donald F. Vitaliano. 2007. An empirical analysis of the strategic use of corporate social responsibility. Journal of Economics \& Management Strategy 16: 773-92.

Simon, Herbert A. 1945. Administrative Behavior: A Study of Decision-Making Processes in Administrative Organization. New York: The Free Press. 
Spence, Laura J., René Schmidpeter, and André Habisch. 2003. Assessing social capital: Small and medium sized enterprises in Germany and the UK. Journal of Business Ethics 47: 17-29. [CrossRef]

Suchman, Marck C. 1995. Managing legitimacy: Strategic and institutional approaches. Academy of Management Review 20: 571-610. [CrossRef]

Sun, Wenbin, Shanji Yao, and Rahul Govind. 2019. Reexamining corporate social responsibility and shareholder value: The inverted-U-shaped relationship and the moderation of marketing capability. Journal of Business Ethics 160: 1001-17. [CrossRef]

Syn, Juliette. 2014. The social license: Empowering communities and a better way forward. Social Epistemology 28: 318-39. [CrossRef]

Taliento, Marco, Christian Favino, and Antonio Netti. 2019. Impact of environmental, social, and governance information on economic performance: Evidence of a corporate 'sustainability advantage' from Europe. Sustainability 11: 1738. [CrossRef]

Teixeira, Ana, Marisa R. Ferreira, Aldina Correia, and Vanda Lima. 2018. Students' perceptions of corporate social responsibility: Evidences from a Portuguese higher education institution. International Review on Public and Nonprofit Marketing 15: 235-52. [CrossRef]

Tello, Carlos, and María del Pilar Rodríguez. 2014. Conceptual categories of the study organizational social responsibility. Hallazgos 11: 119-35.

Thorne, Linda, Lois S. Mahoney, Kristen Gregory, and Susan Convery. 2017. A comparison of Canadian and US CSR strategic alliances, CSR reporting, and CSR performance: Insights into implicit-explicit CSR. Journal of Business Ethics 143: 85-98. [CrossRef]

Tollin, Karin, and Lars B. Christensen. 2019. Sustainability marketing commitment: Empirical insights about its drivers at the corporate and functional level of marketing. Journal of Business Ethics 156: 1165-85. [CrossRef]

Trevino, Linda K. 1992. Moral reasoning and business ethics: Implications for research, education, and management. Journal of Business Ethics 11: 445-59. [CrossRef]

Turner, Megan R., Tristan McIntosh, Shane W. Reid, and M. Ronald Buckley. 2019. Corporate implementation of socially controversial CSR initiatives: Implications for human resource management. Human Resource Management Review 29: 125-36. [CrossRef]

Uribe-Macías, Mario E., Óscar A. Vargas-Moreno, and Luis Merchán-Paredes. 2018. Corporate social responsibility and sustainability, enabling criteria in projects management. Entramado 14: 52-63. [CrossRef]

Vázquez, José Luis, Ana Lanero, and Oscar Licandro. 2013. Corporate social responsibility and higher education: Uruguay university students'perceptions1. Economics E Sociology 6: 145-57.

Verčič, Anna T., and Dubravka S. Ćorić. 2018. The relationship between reputation, employer branding and corporate social responsibility. Public Relations Review 44: 444-52. [CrossRef]

Vogel, David J. 2005. Is there a market for virtue? The business case for corporate social responsibility. California Management Review 47: 19-45.

Waheed, Abdul, Qingyu Zhang, Yasir Rashid, Muhammad Sohail Tahir, and Muhammad Wasif Zafar. 2020. Impact of green manufacturing on consumer ecological behavior: Stakeholder engagement through green production and innovation. Sustainable Development 28: 1-9. [CrossRef]

Walton, Clarence C. 1967. Corporate Social Responsibilities. Belmont: Wadsworth Publishing Company.

Wang, Jia, and Betty S. Coffey. 1992. Board composition and corporate philanthropy. Journal of Business Ethics 11: 771-78. [CrossRef]

Wang, Shuo, and Yuhui Gao. 2016. What do we know about corporate social responsibility research? A content analysis. The Irish Journal of Management 35: 1-16. [CrossRef]

WCED, Special Working Session. 1987. World Commission on Environment and Development. Our Common Future 17: 1-91.

Weng, Hua-Hung Robin, Ja-Shen Chen, and Pei-Ching Chen. 2015. Effects of green innovation on environmental and corporate performance: A stakeholder perspective. Sustainability 7: 4997-5026. [CrossRef]

Wilson, Emma. 2016. What is the social licence to operate? Local perceptions of oil and gas projects in Russia's Komi Republic and Sakhalin Island. The Extractive Industries and Society 3: 73-81. [CrossRef]

Wójcik, Piotr. 2018. The business case for corporate social responsibility: A literature overview and integrative framework. Journal of Management and Business Administration. Central Europe 26: 121-48.

Wood, Donna J. 1991. Corporate social performance revisited. Academy of Management Review 16: 691-718. [CrossRef] 
Yasser, Qaiser Rafique, Abdullah Al Mamun, and Irfan Ahmed. 2017. Corporate social responsibility and gender diversity: Insights from Asia Pacific. Corporate Social Responsibility and Environmental Management 24: 210-21.

Yin, Juelin, and Dima Jamali. 2016. Strategic corporate social responsibility of multinational companies subsidiaries in emerging markets: Evidence from China. Long Range Planning 49: 541-58. [CrossRef]

Zadek, Simon, John Sabapathy, Helle Døssing, and Tracey Swift. 2003. Responsible Competitiveness: Corporate Responsibility Clusters in Action. New York: Institute of Social \& Ethical AccountAbility.

Zeimers, Geraldine, Christos Anagnostopoulos, Thierry Zintz, and Annick Willem. 2019. Organisational learning for corporate social responsibility in sport organisations. European Sport Management Quarterly 19: 80-101. [CrossRef]

Zerbini, Fabrizio. 2017. CSR initiatives as market signals: A review and research agenda. Journal of Business Ethics 146: 1-23. [CrossRef]

Zhou, Haidi, Qiang Wang, and Xiande Zhao. 2020. Corporate social responsibility and innovation: A comparative study. Industrial Management $\mathcal{E}$ Data Systems 120: 863-82.

Zyznarska-Dworczak, Beata. 2018. Legitimacy Theory in Management Accounting Research. Problemy Zarzadzania 16: 195-203. [CrossRef]

(C) 2020 by the authors. Licensee MDPI, Basel, Switzerland. This article is an open access article distributed under the terms and conditions of the Creative Commons Attribution (CC BY) license (http://creativecommons.org/licenses/by/4.0/). 